\title{
A Research on the Relationship Between Organizational Cynicism and Organizational Commitment: Textile Sector Example
}

\author{
Nilüfer Rüzgar ${ }^{1 *} \quad$ Buse Bedel $^{2}$ \\ 1.Assist. Prof. Dr., Faculty of Humanities and Social Scşences, Department of Business Administration, Bursa \\ Technical University Yıldırım Bursa 16330, Turkey \\ 2.MBA Student, Social Sciences Instıtute, Bursa Technical University Yıldırım Bursa 16330, Turkey
}

\begin{abstract}
Organizational commitment is a positive business behavior that expresses the sense of belonging and commitment developed by the employee towards the organization in which he/she is working. Organizational cynicism, which has a diminishing effect on this positive work behavior, is the totality of negative beliefs, feelings and thoughts developed by the employee towards the organization. This study aims to discuss the relationship between organizational commitment and organizational cynicism The sample of the research is defined as the employees in organizations that are active in textile sector in the city of Bursa Nilüfer Organized Industrial Zone. In this context, a questionnaire consisting of 3 parts is used as data collection tool. The first section of the questionnaire there are demographical questions. In the second section, there is Organizatiobal Cynicism Scale, which is developed by Brandes, Dhaldwadk and Dean (1999) and in the third section there is Organizational Commitment Scale, which is developed by Meyer and Allen (1991). 250 surveys have been distributed to participants via e-mail and 179 respond are received. The collected data were analyzed using SPSS 22.0 package program. According to the findings there is statistically significant relationship between organizational Cynicism and all 3 dimensions of Organizational Commitment. There are various researches on the relationship between organizational commitment and organizational cynicism in both international and national literature. On the other hand, there is almost no study dealing with this relationship in the context of the textile sector. At this point, it is hoped that this work will constitute originality, and it is expected that a more detailed national framework will be created in the future, not only in the textile sector, but also in the private and public sectors. In addition to this, it is hoped that professionals would gain awareness about the human resources in their organizations based on the results of these and similar studies.
\end{abstract}

Keywords: Organizational commitment, Organizational cynicism, Textile sector

DOI: $10.7176 / \mathrm{EJBM} / 12-12-09$

Publication date: April $30^{\text {th }} 2020$

\section{Introduction}

The intensification of the competition in the business world in recent years and the intense pressure created by globalization have caused management approaches to focus on the employees and the importance given to the human element within the organization has increased. The ability of organizations to cope with increasingly competitive conditions depends only on the presence of employees who feel a high degree of commitment to the values of the organization, accept the goals and objectives of the organization as their personnel goals and objectives and act accordingly. At this point, the concept of organizational commitment (Mowday, Steers and Porter, 1979: 226), which is defined as "the belief in the values of the organization, the desire to make efforts to fulfill the goals and objectives of the organization, the desire and enthusiasm towards maintaining the organization membership", is more and more important for organizations. In this context, increasing the commitment of qualified employees with know-how has become the focus of organizations, while optimizing the satisfaction of the employees to achieve this increase is seen as the basic goal of producing goods / services by organizations. Although the management of the organizations consider ensuring the satisfaction of the employees as among the main purposes in order to achieve organizational goals and thus, try to eliminate the factors that decrease the satisfaction, there may be many human-related problems that prevent the formation and development of this link between the organization and the employee. Organizational cynicism (Dean, Brandes and Dharwadkar, 1998: 341), which is defined as the "negative attitudes of the employee towards the organization", is the leading problem. The attitudes and thoughts of the employees who play a serious role in the success of the organizations are extremely important. The negative attitudes and thoughts of these employees' towards the organization can reduce the loyalty and commitment as well, which is seen as among the most important factors in achieving organizational strategic goals. From this point of view, the purpose of this study is to discuss the relationship between organizational commitment and organizational cynicism attitudes of employees that work in textile sector in Bursa city.

\section{Organizational Commitment}

The concept of commitment can be defined as a way of expressing the feeling of social instinct that exists in every area where the concept of society is dominant (Şenturan, 2014: 171). The concept of commitment was first 
discussed within the organization in William Whyte's (1956) work titled "The Person of the Organization." This study, which Whyte defined the organizational person as an entity belonging to the organization as well as being a person working in the organization, paved the way for the increase and gaining importance of the researches on the concept of "organizational commitment" (Randall, 1987: 460).

The issue of organizational commitment was first handled by Whyte in 1956, and has been studied by many researchers from different disciplines such as Porter, Mowday, Steers, Allen, Meyer and Becker (Gül, 2002: 37). The concept of organizational commitment as a subject of research in different disciplines such as organizational and social psychology caused researchers to approach the concept with their own perspectives (Candan and Yetim, 2018: 3443). When the organizational commitment literature is analyzed, it is thought that this is the main reason for encountering many different definitions rather than a single definition of concept (Oliver, 1990: 21).

Becker (1960: 32) defines the concept of organizational commitment as a commitment resulting from the thought that the gains of the employees from the organization in addition to their efforts, be wasted when it comes to leaving the organization. It defines it as a bond, which causes the employees to decide to continue working in the organization. When other studies conducted within the scope of organizational commitment are analyzed, organizational commitment is expressed by Mathews and Sheppard as a strong willingness to adopt the values and goals of the organization based on the benefit of the organization and to remain as a member of the organization (Mathews \& Sheppard, 2002: 369 ).

Among the definitions of organizational commitment, the most common one belongs to Porter et al. (Uçar \& Kök, 2018: 235). Porter et al. (1974: 604) mentioned three factors that characterize organizational commitment: The belief and acceptance developed for the aims and values of the organization, the desire to make a high degree of effort on behalf of the organization and the desire to maintain membership in the organization. In the light of the definitions made, it is possible to summarize the concept of organizational commitment as the desire of the employee to remain in the organization, high level of interest and effort for the organization to be successful, integration of the organization with its values, goals and objectives, and the loyalty attitude developed towards the organization (Bayram, 2005: 128).

In studies conducted on the concept of organizational commitment, it is seen that the concept has been examined by many authors by considering different dimensions. For example; While researchers such as Becker, Staw, Salancik highlight the behavioral aspect of the concept, researchers such as Allen, Meyer, Mowday, Steers and Porter focused on the attitude direction of the concept (Y1ld1z, 2013: 855). In this context, various studies carried out within the scope of organizational commitment and different definitions caused different classifications (Taş, 2012: 11).

Among these classifications, the most used and accepted model in the organizational commitment literature is the Meyer and Allen model consisting of 3 dimensions (Koyuncu \& Elçi, 2018: 67). Allen and Meyer argue that organizational commitment consists of 3 different dimensions: affective, continuance and normative (Meyer, Irving and Allen, 1998: 32). In addition, this model also includes the relationships between the elements that make up the organizational commitment and the different variables and organizational results.

\subsection{Affective Commitment}

Affective commitment; is the identification of the employees with the organization, their commitment to the organization (Allen \& Meyer, 1996: 253) and therefore their desire not to leave the organization (Meyer, Stanley and Parfyonova, 2012: 1; Meyer, Stanley, Jackson, McInnis, Maltin and Sheppard, 2012: 226). The affective commitment of the employee to the organization means that the person is in that organization because he / she wants it. Those who work in the organization voluntarily do not refrain from taking additional responsibility and making extra efforts when necessary because they are loyal and committed employees and show a completely positive attitude towards the job and the organization (Çetin, 2004: 95). For this reason, affective commitment is the most desired type of commitment to be created by employers in organizations (Afşar, 2011: 10). The findings obtained from the previous researches show that those who work with affective commitment make more meaningful and positive contributions to their organizations compared to employees with continuance commitment (Çakıroğlu, Çöp and Altınöz, 2018: 3685). Furthermore, if employees' affective commitment is strong, their normative commitment also strengthens. Because employees think that it is true and ethical to stay in the organization in addition to their high levels of satisfaction and they also volunteer to make extra efforts on behalf of the organization (Meyer et al., 2012: 14).

\subsection{Continuance Commitment}

It is the type of commitment that emerges as a result of the investments (pshyically and mentally) made by the employees for the organization they are affiliated with. In this case, the employee thinks that staying in the organization is an imperative because of the effort and time that is spent fort he organization (Bayram, 2005: 133). Unlike affective commitment, in continuance commitment the cost factor is the determining factor in the desire of the employees to continue their organization membership (Ersoy \& Bayraktaroğlu, 2015: 5). These people, who 
are obliged to work for their employers, are called trapped workers because they are the ones who will end their membership of the organization without hesitation if they can. Some of these people remain in their organization because they are unable to find a job or do not have the competencies and qualifications to find a job, while others remain in their organization for compelling reasons such as close retirement or health issues. In addition, these individuals can be a source of problems for managers since they are not loyal to the organization and display negative attitudes (Çetin, 2004: 95).

\subsection{Normative Commitment}

Normative commitment is the type of commitment that emerges as a result of the belief that the service is debt for the organization and morally correct, in response to the opportunities and investments provided by the organization for them (Gül, 2002: 45; Allen a\& Meyer, 1991: 72). The main focus in normative commitment is to emphasize the necessity (McInnis, Meyer and Feldman, 2009: 166). The employee, who has normative commitment, believes that he/she has an obligation and responsibility for the organization he/she works for and therefore considers remaining in the organization as an ethical issues (Wasti, 2002: 526). Normative commitment can also occur when the organization facilitates paying interest such as rewards, educational scholarships or participation in certain courses. This situation normatively connects the employee to the organization, as the employee feels owed to the organization. The idea of commitment created in this way can only end when the employee pays his/her debt to the organization (Meyer \& Allen, 1991: 72). In short, the employee believes that the sense of normative commitment to the organization is important and morally imperative in this regard (Doğan \& Kılıç, 2007: 49).

To sum up, the common point of the affective, continuance and normative commitment types developed by Allen and Meyer is the existence of a link between the organization and the employee that reduces the possibility of leaving the organization. Namely; each type of commitment connects the employee to the organization and ensures its continuity. But, the reasons to be committed to the organization differs in each type. The motivation of staying in the organization in affective commitment is based on desire, need in continuance commitment and moral obligation in normative commitment (Obeng \& Ugboro, 2003: 83).

\section{Organizational Cynicsm}

Cynicism is a philosophical way of thinking that is originated in the ancient Greek period and based on the rules of nature, ignoring moral rules. Although the most known representative of this movement, which is accepted to have emerged in the 500s B.C., is Diogenes, Antisthenes, who went the path of Socrates, is also known as the first representative and the first cynic (Mantere \& Martinsuo, 2001: 4).

Cynicism is a special and general attitude that includes negative feelings such as anger as well as disdain, despair and insecurity towards an ideology, person, group or institution (Andersson, 1996: 154). Organizational cynicism, on the other hand, is defined as the whole of beliefs that the organization in which individuals work are devoid of honesty and that basic principles such as justice and sincerity are sacrificed for the interests of the organization (Bernerth, Armenakis, Feild, and Walker, 2007: 311). While organizational cynicism can be associated with too many objects, it represents an attitude that can be generalized from one target to another, and the learned belief that develops as a result of experience (Görmen, 2017: 366). In this framework, organizational cynicism has been defined by James (2005: 7) as "an answer to the past of personal and social experiences that are shaped by the negative feelings, beliefs and behaviors of a person, but also connected with the attitudes I have regarding the organization of the employer and are open to be affected by environmental factors".

As mentioned above, the concept of cynicism dates back to ancient times, while studies on organizational cynicism in the literature, especially in the field of organizational behavior, started to gain momentum in the late 1980 s and early 1990s. In this context, the concept of organizational cynicism was brought into the literature by Kanter and Mirvis (1989) to investigate the causes of cynicism in the organization. Afterwards, the effects of cynicism were started to be examined and discussed by the American public, politicians and company executives (James, 2005: 18)

Although organizational cynicism is classified under 5 different cathegories as corporate cynicism, personality cynicism, organizational change cynicism, vocational cynicism and employee cynicism, these cathegories are also gathered under an umbrella. The fact that organizational cynicism acts as an umbrella that combines these classifications is due to the fact that all five types of cynicism occur within the organization. Sometimes, although there is a difference in the goals or causes of cynicism, all cathegories of organizational cynicism include negative feelings, thoughts, beliefs and behaviors related to the organization (Torun, 2016: 52). 
Table 1. Main Forms of Organizational Cynicism

\begin{tabular}{|l|l|l|l|l|}
\hline & Attitude & Goal & Context & Time \\
\hline Personality Cynicism & $\begin{array}{l}\text { Brutality and } \\
\text { Anger }\end{array}$ & Human Nature & $\begin{array}{l}\text { Fixed Personality } \\
\text { Trait }\end{array}$ \\
\hline Corporate Cynicism & $\begin{array}{l}\text { Alienation and } \\
\text { Despair }\end{array}$ & Institutions & Constant \\
\hline Employee Cynicism & Pain and Blocking & Anything & $\begin{array}{l}\text { Possibility of } \\
\text { Change }\end{array}$ & Constant \\
\hline $\begin{array}{l}\text { Organizational Change } \\
\text { Cynicism }\end{array}$ & $\begin{array}{l}\text { Frustration and } \\
\text { Pessimism }\end{array}$ & $\begin{array}{l}\text { Organizational } \\
\text { Change }\end{array}$ & $\begin{array}{l}\text { Unsuccessful } \\
\text { Change }\end{array}$ & Constant \\
\hline Vocational Cynicism & $\begin{array}{l}\text { Leaving } \\
\text { Complaints }\end{array}$ & Customer & $\begin{array}{l}\text { Service } \\
\text { Organizations }\end{array}$ & Constant \\
\hline
\end{tabular}

Source: Delken, M. (2004). Organizational Cynicism: A Study Among Call Centers. University of Maastricht Faculty of Economics and Business Administration Department of Organization and Strategy, s.15.

Corporate cynicism is also called social cynicism, and it expresses the insecurity of people living in a country to their own institutions and government administrators (Donald \& Philip, 2009: 4), while the negative attitude of the vocational cynicism occurs due to disappointment and insecurity towards the organization where the employee works (Cartwright and Holmes, 2006: 200). Personality cynicism, on the other hand, is the only type of cynicism, a feature that exists in the nature of the person, which causes the behaviors displayed by people to be perceived as negative (Abraham, 2000: 270). On the other hand, organizational change cynicism is considered as a belief in pessimism and inadequacy of the people who will make the change in the future (Abraham, 2000: 272; Reichers, Wanous and Austin, 1997: 48), while vocational (business) cynicism is expressed as a negative attitude towards the content of the work done (Abraham, 2000: 273).

When the literature is examined, it is seen that there are many factors that will trigger the formation of organizational cynicism. The main factors that have important impacts on the formation of organizational cynicism can be expressed as follows: Job satisfaction and commitment to the organization (Nafei, 2013: 52), high manager wages, sudden and harsh layoffs (Andersson \& Bateman, 1997: 451), perceived reduced organizational support (Kalağan 2009: 89), high level of role conflict (Naus, Iterson \& Roe, 2007: 693), psychological contract violation (Delken, 2004: 18), long working hours, ineffective leadership and management, intense work load, organizational downsizing (Cartwright and Holmes, 2006: 201).

However, organizational cynicism is known to have some negative effects on employees and organizations. These negative effects can be listed as follows: Increase in the rates of dismissal, disobedience, insecurity, increase in burnout level, decrease in motivation, decrease in performance within the organization, decrease in self-esteem, decrease in trust in the organization (Kalağan, 2009: 81).

According to Dean and his friends, organizational cynicism, which is expressed as a negative attitude towards the organization, consists of three dimensions. These are belief that the organization lacks integrity (cognitive), negative feelings (affective) towards the organization (malicious emotional) and abusive (negative) tendencies and behaviors related to the organization (Dean et al., 1998: 345).

\subsection{Cognitive (Belief) Dimension}

The cognitive dimension is expressed in the belief that there is no honesty in the organization (Dean et al., 1998: 343). In other words, employees feel insecurity towards the decisions of the organization and believe that they do not reflect the real character of their managers, which is explained by the cognitive dimension of organizational cynicism (Helvacı \& Cetin, 2012: 1477). People with cynical attitudes in organizations have beliefs that practices in organizations lack organizational principles, that human behavior in organizations is inconsistent and unreliable, and that relationships in the organization are based on personal interests, so that they can behave immorally by ignoring value judgments such as sincerity and honesty for the interests of employees. (Kalağan, 2009: 46).

Negative attitudes of cynical organization members are can be listed as stigma, disorganization, alienation, lovelessness, lack of attention, emotional numbness and burnout (Akman, 2013: 35).

\subsection{Affective (Feelings) Dimension}

Those who feel affective cynicism, give strong emotional reactions such as anger, disdain and shame about the organization they work in (Özler, Atalay \& Şahin, 2010: 49). They adopt feelings such as hate, distress and shame, and in addition, they can make harsh criticism about the lack of principles such as honesty and justice in their organizations. (Brandes, Dharwadkar and Dean, 1999: 5). Therefore, it can be said that cynicism is associated with many negative emotions (Dean et al., 1998: 346). Anger, disrespect, anger, disdain, hate, moral deterioration, disappointment, despair, feelings of shame, disdain, self-indulgence and distrust are among the negative emotions of affective cynicism (İraz, Fındık \& Eryeven, 2012: 447). 


\subsection{Behavioral Dimension}

Behavioral dimension is expressed as the tendency to exhibit negative behavior towards the organization (İnceoğlu, 2010: 25). The behavioral dimension of organizational cynicism is that the employee, who is a member of the organization, conveys negative information about the organization, makes criticisms and complaints. In this context, employees who exhibit cynical attitudes towards the organization tend to make desperate and pessimistic predictions about the future activities of the organization and they can humiliate and offend people (Dean et al., 1998: 346). People who exhibit cynical behavior in organizations can also display their negative thoughts with their non-verbal behavior. In this sense, behaviors such as employees' looking at each other meaningfully and smiling cynically are among the examples that can be given to cynical behaviors (Brandes et al., 1999: 5).

\section{Studies Investigating the Relationship Between Organizational Commitment and Organizational Cynicism}

When the researches on organizational commitment and organizational cynicism are examined, it is seen that the number of studies examining the relationship between the two concepts are not adequate. In this context, some of the studies that can be reached in both international and national literature are given below.

In the study conducted by Nafei and Kaifi (2013), the relationship between organizational cynicism and organizational commitment of 297 employees working in institutions providing education to doctors was measured. According to the findings obtained from the research, there is a significant relationship between organizational commitment and organizational cynicism levels of the employees.

In the study conducted by Barnes (2010), the sample of which was composed of 473 college employees, the relationship among organizational commitment, organizational cynicism and organizational citizenship behaviors is examined. It was concluded that those who exhibit cynical attitudes had lower commitment to the organization.

Brandes, Dharwadkar and Dean (1999) examined the relationships among organizational cynicism, organizational commitment, organizational citizenship, employee involvement, the manager's formal behavior, the manager's extra behavior, and the manager's involvement. The sample of the research consists of 129 employees and managers working in a medium-sized organization. In the findings obtained from the results of the research, it was found that there was a strong and negative relationship between organizational cynicism and organizational commitment. Another finding of this study was that there was a difference in organizational cynicism attitudes of managers and employees. In this context, it was concluded that those who work cynically had higher organizational commitment and participation compared to managers.

As for national studies, Yavuz and Bedük (2016) selected 85 people working in a public bank as sample in their study on the relationship between organizational cynicism and organizational commitment. This study was carried out to investigate the relationship between organizational commitment and organizational cynicism, to reveal the relationships between its sub-dimensions and to determine whether there is a relationship among demographical characteristics and organizational commitment and organizational cynicism levels. According to the results obtained from the study, there was a negative relationship between organizational cynicism and organizational commitment behavior. While a statistically significant difference was found between demographical characteristics gender and educational status, there was a statistically significant difference between the demographical characteristics of organizational cynicism only between the groups in the educational situation.

Türközü, Parker and Cos (2013) carried out a research in a leading company that is active in textile sector, Turkey, within the framework of structural equation model and collected data from 371 employees via survey method. As a result of the research, it was determined that organizational cynicism and organizational trust perceptions predicted the organizational commitment variable. However, it was another finding that the perceptions of organizational cynicism negatively affected the variable of organizational commitment.

Findik and Eryeşil (2012), aimed to investigate the effect of the cynical attitudes of the employees working in the iron and steel enterprises in Konya, on their organizational commitment. It was concluded that organizational cynicism, which occured in the employees as a result of the changes experienced in the research, had the effect of reducing the organizational commitment of the employees. Although it was concluded that there was a negative relationship between organizational cynicism and organizational commitment, it was determined that the age, education, working time of the employees differ according to the variables of organizational cynicism and organizational commitment.

In the research conducted by Altınöz, Çöp and Sığındı (2011), the relationship between the organizational cynicism and organizational commitment of 210 managers working in four and five stars hotel businesses operating in Ankara was analyzed statistically. According to the findings obtained in the study, there is a highlevel negative relationship between organizational commitment and organizational cynicism. In this context, it was emphasized that policies should be followed to increase the commitment of the employees in order to prevent the employees from displaying cynical attitudes. When the relationship in the sub-dimensions of organizational cynicism and organizational commitment was analyzed, it was found that there was a generally moderate 
relationship between cynicism and commitment in the opposite direction.

\section{Methodology}

When the researches on organizational commitment and organizational cynicism are examined, it is seen that there are few number of studies examining the relationship between the two concepts. In this context, some of the studies that can be reached in both international and national literature are given above.

In this study, it is aimed to analyze the relationship between organizational cynicism and organizational commitment. The sample of the research is defined as the employees in organizations that are active in textile sector in the city of Bursa Nilüfer Organized Industrial Zone. In this context, a questionnaire consisting of 3 parts is used as data collection tool. The first section of the questionnaire there are demographical questions. In the second section, there is Organizatiobal Cynicism Scale, which is developed by Brandes, Dhaldwadk and Dean (1999) and in the third section there is Organizational Commitment Scale, which is developed by Meyer and Allen (1991). 250 surveys have been distributed to participants via e-mail and 179 respond are received. The collected data were analyzed using SPSS 22.0 package program.

\subsection{Hypothesis}

H0: There is no statistically significant relationship between Organizational Commitment and Organizational Cynicism.

H1: There is a statistically significant relationship between Organizational Cynicism and Normative Commitment h1: $\mu 1>\mu 2$

$\mathrm{H} 2$ : There is a statistically significant relationship between Organizational Cynicism and Attendance Commitment h2: $\mu 1>\mu 2$

H3: There is a statistically significant relationship between Organizational Cynicism and Affectivel Commitment h3: $\mu 1>\mu 2$

\subsection{Demographical Findings}

According to demographical findings, $111(62 \%)$ participants are women and $68(38 \%)$ participants are men. As for age groups, 85 (47.5\%) participants are among 18-29 age group, 75 (14.9\%) participants are among 30-39 age group, $14(7.8 \%)$ participants are among 40-49 age group and $5(2.9 \%)$ participants are $50-59$ age group. 105 $(58.4 \%)$ participants are married, $74(41.6 \%)$ participants are single. $47(26.3 \%)$ participants have 1-5 years work experience, 59 (33\%) participants have 6-10 years experience, 15 (25.1\%) participants have 11-15 years experience, $22(12 \%)$ participants have $16-20$ years experience, $5(2.8 \%)$ participants have $21-25$ years experience and only 1 $(0.6 \%)$ participant has $26+$ years work experience. $6(3.4 \%)$ participants are secondary school graduates, 18 $(10.1 \%)$ participants are high school graduates, $117(65.4 \%)$ participants are university graduates and $38(21.2 \%)$ participants are post-graduates.

\subsection{Reliability Analysis}

The cronbach's alpha value of the Organizational Cynicism Scale is 0.968 and the cronbach's alpha value of the Organizational Commitment Scale is 0.9983 (Table 2).

Table 2. Cronbach's Alpha Values of the Scales

\begin{tabular}{lll}
\hline Scale & Cronbach's Alpha Value & Number of Items \\
\hline Organizational Cynicism &, 968 & 13 \\
Organizational Commitment &, 983 & 18 \\
\hline
\end{tabular}

\subsection{Factor Analysis}

According to the factor analysis (Table 3), the Organizational Commitment Scale has three dimensions. These dimensions are labelled as Normative, Affective and Continuance Commitment, as the original scale. The normative commitment dimension explains the organizational commitment scale with a percentage of 31.991, the affective commitment dimension with a percentage of 17.027 and the continuance commitment dimension with a percentage of 24.971 . The cumulative percentage of all dimensions is $73.988 \%$.

Table 3. Total Variance Explained

\begin{tabular}{lllllll}
\hline & \multicolumn{3}{l}{ Loaded Sum of Squares } & \multicolumn{5}{c}{ Rotated Sum of Squares } \\
\cline { 2 - 6 } Component & Total & Variance & Cumulative\% & Total & \%Variance & Cumulative\% \\
\hline 1 & 5,845 & 48,707 & 48,707 & 3,839 & 31,991 & 31,991 \\
2 & 1,704 & 14,202 & 62,910 & 2,997 & 17,027 & 56,962 \\
3 & 1,329 & 11,079 & 73,988 & 2,043 & 24,971 & 73,988 \\
\hline
\end{tabular}

$4)$. 
Table 4. Total variance Explained

\begin{tabular}{lllllll}
\hline & \multicolumn{2}{l}{ Loaded Sum of Squares } & \multicolumn{3}{l}{ Rotated Sum of Squares } \\
\cline { 2 - 6 } Component & Total & \%Variance & Cumulative\% & Total & \%Variance & Cumulative\% \\
\hline 1 & 7,923 & 79,231 & 79,231 & 7,923 & 79,231 & 79,231
\end{tabular}

\subsection{Regression Findings Related to Hypothesis}

H1: There is a statistically significant relationship between Organizational Cynicism and Normative Commitment. h1: $\mu 1>\mu 2$

According to the model summary table of the hypothesis (Table 5), the independent variable Organizational Cynicism, has a regression value of $33.7 \%$ on Normative Commitment.

Table 5. Model Summary

\begin{tabular}{lllll}
\hline & & & \multicolumn{2}{c}{ Adjusted $\begin{array}{l}\text { Standard } \\
\text { Deviation }\end{array}$} \\
\hline 1 & $\mathrm{R}$ & $\mathrm{R}^{2}$ & $\mathrm{R}^{2}$ & 5,69098 \\
\hline
\end{tabular}

When the ANOVA values of the model are analyzed (Table 6), it is seen that the F value is statistically significant at the first phase. $\mathrm{p}<.001$. (F178-1 = 90.094).

Table 6. ANOVA Values

\begin{tabular}{|c|c|c|c|c|c|c|}
\hline \multicolumn{2}{|c|}{ Phase } & Sum of Squares & df & Sum of Averages & $\mathrm{F}$ & $\mathrm{p}$ \\
\hline & Regression Value & 2917,900 & 1 & 2917,900 & 90,094 &, 000 \\
\hline & Residual & 5732,536 & 177 & 32,387 & & \\
\hline & Total & 8650,436 & 178 & & & \\
\hline
\end{tabular}

There is a statistically significant relationship between Organizational Cynicism and Normative Commitment ( $\mathrm{p}$ $<, 01$ ). If Organizational Cynicism increases one unit, Normative Commitment - decreases ,581 units (Table 7).

h1: There is a statistically significant relationship between Organizational Cynicism and Normative Commitment.

Table 7. Coefficients

\begin{tabular}{llllll}
\hline & \multicolumn{2}{l}{ Untandardized Coefficients } & Standardized Coefficients & & \\
\cline { 2 - 4 } Phase & $\mathrm{B}$ & Standard Deviation & Beta & $\mathrm{t}$ & $\mathrm{p}$ \\
\hline $1 \quad$ Normative Commitment) & 24,333 & 1,027 & & 23,688 &, 000 \\
\multicolumn{1}{c}{ Organizational Cynicsm } &,- 337 &, 035 &,- 581 & $-9,492$ &, 000 \\
\hline
\end{tabular}

Dependent Variable: Normative Commitment

$\mathrm{H} 2$ : There is a statistically significant relationship between Organizational Cynicism and Continuance Commitment. h2: $\mu 1>\mu 2$

According to the model summary of this hypothesis (Table 8), there is a regression value of $54.6 \%$ on the Continuance Commitment of the independent variable Organizational Cynicism.

Table 8. Model Summary

\begin{tabular}{lllll}
\hline & & & \multicolumn{2}{c}{ Adjusted $\begin{array}{l}\text { Standard } \\
\text { Deviation }\end{array}$} \\
Phase & $\mathrm{R}$ & $\mathrm{R}^{2}$ & $\mathrm{R}^{2}$ & 3,16039 \\
\hline 1 & $, 739^{\mathrm{a}}, 546$ &, 544 & 34
\end{tabular}

When the ANOVA values of the model are examined (Table 9), it is seen that the F value is statistically significant at the first phase. $\mathrm{p}<.001$. $(\mathrm{F} 178-1=213.107)$.

Table 9. ANOVA Values

\begin{tabular}{|c|c|c|c|c|c|}
\hline Phase & Sum of Squares & $\mathrm{df}$ & Sum of Averages & $\mathrm{F}$ & $\mathrm{p}$ \\
\hline 1 Regression Value & 2128,519 & 1 & 2128,519 & 213,107 &, 000 \\
\hline Residual & 1767,883 & 177 & 9.988 & & \\
\hline Total & 3896,402 & 178 & & & \\
\hline
\end{tabular}

There is a statistically significant relationship between Organizational Cynicism and Continuance Commitment ( $\mathrm{p}$ $<, 01)$. If Organizational Cynicism increases 1 unit, Continuance Commitment increases 739 units (Table 10).

h2: There is a statistically significant relationship between Organizational Cynicism and Continuance Commitment. Table 10. Coefficients Table

\begin{tabular}{|c|c|c|c|c|c|}
\hline \multirow[b]{3}{*}{ Phase } & \multicolumn{2}{|c|}{ Unstandardized Coefficients } & \multirow[t]{2}{*}{ Standardized Coefficients } & \multirow[b]{3}{*}{$\mathrm{t}$} & \multirow[b]{3}{*}{$\mathrm{p}$} \\
\hline & & Standart & & & \\
\hline & B & Sapma & Beta & & \\
\hline 1 (Continuance Commitment) & ,805 &, 570 & & 1,412 &, 160 \\
\hline Organizational Cynicism & ,288 & 020 & ,739 & 14,598 &, 000 \\
\hline
\end{tabular}

Dependent Variable: Continuance Commitment

H3: There is a statistically significant relationship between Organizational Cynicism and Affective Commitment. h3: $\mu 1>\mu 2$ 
According to the model summary table of this hypothesis (Table 11), the independent variable Organizational Cynicism has a regression value of $64.6 \%$ on Affective Commitment.

Table 11. Model Summary

\begin{tabular}{lllll}
\hline & & & Adjusted & Standard \\
Phase & $\mathrm{R}$ & $\mathrm{R}^{2}$ & $\mathrm{R}^{2}$ & Deviation \\
\hline 1 & $, 530^{\mathrm{a}}, 281$ &, 277 & 2,95996 \\
\hline
\end{tabular}

According to the ANOVA table of the model (Table 12), $\mathrm{F}$ value is statistically significant at the first phase. $\mathrm{p}$ $<.001$. $(\mathrm{F} 120-2=107.800)$

Table 12. ANOVA Values

\begin{tabular}{llllll}
\hline Phase & Sum of Squares & df & Sum of Averages & F & $p$ \\
\hline $1 \quad$ Regression Value & 607,221 & 1 & 607,221 & 69,307 &, 000 \\
Residual & 1550,757 & 177 & 8,761 & & \\
$\quad$ Total & 2157,978 & 178 & & & \\
\hline
\end{tabular}

There is a statistically significant relationship between Organizational Cynicism and Affective Commitment $(\mathrm{p}<$, 01). If Organizational Cynicism increases 1 unit, Affective Commitment increases 183 units (Table 13).

h3: There is a statistically significant relationship between Organizational Cynicism and Affective Commitment. Table 13. Coefficients

\begin{tabular}{llllll}
\hline & \multicolumn{2}{l}{ Unstandardized Coefficients } & Standardized Coefficients & \\
\cline { 2 - 4 } Phase & Standard & Beta & t & $\mathrm{p}$ \\
\hline $1 \quad$ (Organizational Cynicism) & 3,417 & 1,411 & & 2,422 &, 000 \\
\multicolumn{1}{c}{ Affective Commitment } &, 180 &, 115 &, 183 &, 1571 &, 000 \\
\hline
\end{tabular}

Dependent Variable: Affective Commitment

\section{Conclusion and Discussion}

Even though the managements of the organizations give great importance to satisfying the employees, there may be many other obstacles that would prevent the satisfaction and thus, the commitment. Organizational cynicism (Dean, Brandes, \& Dharwadkar, 1998: 341), which is defined as the "negative attitudes of the individual towards the organization" is among these problems. In this sense, organizational commitment levels and types of employees constitute great importance.

Organizational commitment is classified under 3 dimensions as affective, continuance and normative. What type of commitment the employees have and whether there is a relationship between these commitment types and the cynical behaviors they display is a very important issue to be taken into consideration by the organization's management. This is because the human resource is the most valuable resource of the organization and it is extremely costly to replace the lost human resource.

The sample of the research is defined as the employees in organizations that are active in textile sector in the city of Bursa Nilüfer Organized Industrial Zone. According to the findings there is statistically significant relationship between organizational Cynicism and all 3 dimensions of Organizational Commitment. As organizational cynicism behavior increase; Continuance Commitment and Affective Commitment increase accordingly and Normative Commitment decrease. In this sense, when evaluated on sector basis, it can be said that displaying cynical behaviors causes textile sector employees to stay away from moral (normative) attitudes, which is actually an expected result. On the other hand, while it is again among the expected results that continuance commitment increase as organizational cynicism behaviour increase, it is quite unexpected that affective commitment increase in accordance with the increase of organizational cynicism. In this sense, it can be predicted that although the employees in textile sector reduce their normative behaviour and continue to work just for their personnel interests, they try to make themselves feel positive because of the fact that employees spend their all day in their organizations. Therefore, it can be concluded that they feel positive as they freely express their cynical attitudes.

It is thought that conducting similar researches in future studies in different sectors, which are not limited to the textile sector, may help to draw a general profile of the city in terms of all sectors. In addition, it is thought that the expansion of similar studies on the sector basis, first in the city, then in the region and then in the country, will provide an opportunity to compare various sectors with each other as well as drawing a sector-based national framework. In this sense, top management teams would be more conscious about the steps they should take to increase organizational commitment.

\section{References}

Abraham, R. (2000), Organizational Cynicism: Bases And Consequences, Generic, Social And General Psychology Monographs, 126(3), s.269-292.

Afşar T. S. (2011), Çalışma Yaşam Kalitesinin Örgütsel Băglllık Düzeyi Üzerindeki Etkisi: Devlet Ve Vakıf 
Üniversitelerinde Çalışan Akademisyenler Üzerine Nicel Bir Araştırma, Unpublished PhD Dissertation, Hacettepe University Social Sciences Institute, Ankara.

Akman, G. (2013), Sağlık Çalışanlarının Örgütsel Ve Genel Sinizm Düzeylerinin Karşılaştırılması, Unpublished Master's Dissertation, İstanbul University Social Sciences Institute, Department of Management in Hospitals and Health Corporations, İstanbul.

Allen, N. J., \& Meyer, J.P (1996), Affective, Continuance, And Normative Commitment To The Organization: An Examination Of Construct Validity, Journal Of Vocational Behavior, 49(3), s.252-276.

Altınöz, M., Çöp, S. \& Sığındı, T. (2011), Algılanan Örgütsel Bağlılık Ve Örgütsel Sinizm İlişkisi: Ankara’daki Dört Ve Beş Yıldızlı Konaklama İşletmeleri Üzerine Bir Araştırma, Sosyal Ve Ekonomik Araştırmalar Dergisi, 11(21), s.285-315.

Andersson, L. (1996), Employee Cynicism: An Examination Using A Contract Violation Framework, Human Relations. 49(11), s.1395-1418.

Andersson, L. \& Bateman, T. (1997), Cynicism In The Work Place: Some Causes And Effects, Journal Of Organizational Behaviour. 18(5), s.449-469.

Barnes, L. (2010), The Effects Of Organizational Cynicism On Community Colleges: Exploring Concepts From Positive Psychology, Unpublished PhD Dissertation, Claremont Graduate University, California.

Bayram, L. (2005), Yönetimde Yeni Bir Paradigma: Örgütsel Bağlılık, Sayıştay Dergisi, 16(59), s.125-139.

Becker, H. (1960), Notes On The Concept Of Commitment, American Journal Of Sociology, 66(1), s.32-40.

Bernerth, J., Armenakis, A., Feild, H. \& Walker, J. (2007), Justice, Cynicism, And Commitment A Study Of Important Organizational Change Variables, The Journal Of Applied Behavioral Science, 43(3), s.303-326.

Brandes, P., Dharwadkar, R. \& Dean, J.W. (1999), Does Organizational Cynicism Matter? Employee and Supervisor Perspectives on Work Outcomes, 36TH Annual Meeting of the Eastern Academy of Management, Philadelphia, s.1-34.

Candan, H. \& Yetim, Ș. (2018), Kamu Çalışanlarının Örgütsel Sinizm Düzeylerinin Örgütsel Bağlılık Üzerindeki Etkinisi İncelemeye Yönelik Bir Araştırma: Karaman Örneği, Journal of Social and Humanities Sciences Research, 5(29), s.3440-3454.

Cartwright, S. \& Holmes, N. (2006), The Meaning of Work: The Challenge of Regaining Employee Engagement and Reducing Cynicism, Human Resource Management Review, 16(2), s.199-208.

Çakıroğlu, D., Çöp, S. \& Altınöz, M. (2018), İş Doyumu İle Örgütsel Güvenin Örgütsel Bağlılık Üzerine Etkisi: Bir Alan Araştırması, Social Sciences Studies Journal, 4(22), s.3683-3690.

Çetin, Ö. M. (2004), Örgüt Kültürü Ve Örgütsel Baglılık, 1. Baskı, Nobel Yayın Dagıtım, Ankara.

Dean, J. W., Brandes, P. \& Dharwadkar, R. (1998), Organizational Cynicism, The Academy Of Management Review, 23(2), s.341-352.

Delken, M. (2004), Organizational Cynicism: A Study Among Call Centers. Unpublished Master's Dissertation, University Of Maastricht Faculty of Economics And Business Administration Department Of Organization And Strategy, Hollanda.

Doğan, S. \& Kılıç, S. (2007), "Örgütsel Bağlılığın Sağlanmasında Personel Güçlendirmenin Yeri ve Önemi”, Erciyes Üniversitesi İktisadi Ve İdari Bilimler Fakültesi Dergisi, 29, s.37-61.

Donald, L. K. \& Mirvis, P.H. (2009), The Cynical Americans: Living and Working in an Age of Discontent and Disillusion, San Francisco, Ca: Jossey-Bass, 1989. Ayla Zehra Öncer, An Overview of Organizational Cynicism And A Cure Suggestion: Teamwork, Eabr \& Tlc Conference Proceedings, Prague, Czech Republic.

Ersoy, S. \& Bayraktaroğlu, S. (2015), Örgütsel Bağlılık, Editör: Derya Ergun Özler, Örgütsel Davranışta Güncel Konular, 3. Bask1, Ekin Yayınevi, Bursa.

Fındık, M. \& Eryeşil, K. (2012), Örgütsel Sinizmin Örgütsel Bağlılık Üzerindeki Etkisini Belirlemeye Yönelik Bir Araştırma, International Iron And Steel Symposium. 02-04 April, Karabük.

Görmen, M. (2017), Örgüt Kültürünün Örgütsel Sinizm Tutumları Üzerine Etkisi, Bartın Üniversitesi İktisadi Ve İdari Bilimler Fakültesi Dergisi, 8(15), s.363-388.

Gül, H. (2002), Örgütsel Bağlılık Yaklaşımlarının Mukayesesi Ve Değerlendirmesi. Ege Akademik Bakış, 2(1), s.37-56.

Helvacı, M. A. \& Ahmet Çetin, A. (2012), İlköğretim Okullarında Görev Yapan Öğretmenlerin Örgütsel Sinizm Düzeylerinin Belirlenmesi: Uşak İli Örneği, International Periodical For The Languages, Literature And History Of Turkish, 7(3), s.1475-1497.

İnceoğlu, M. (2010), Tutum Algı İletişim, 5. Baskı, Beykent Üniversitesi Yayınevi, İstanbul.

İraz, R., Fındık, M. \& Eryeşil, K. (2012), Algılanan Örgütsel Destek, Örgütsel Bağlılık ve Örgütsel Sinizm İlişkisi: Selçuk Üniversitesi Örneği, 1st International Conference on Sustainable Business and Transitions for Sustainable Development. Sunulmuş Bildiri, Konya.

James, M. (2005), Antecedents and Consequences Of Cynicism In Organizations: An Examination Of The Potential Positive and Negative Effects On School Systems, Unpublished PhD Dissertation, The Florida State University, USA. 
Kalağan, G. (2009), Araştırma Görevlilerinin Örgütsel Destek Algıları İle Örgütsel Sinizm Tutumları Arasındaki İlişki, Unpublished Master's Dissertation, Akdeniz University Social Sciences Institute, Antalya.

Koyuncu, E. \& Elçi, A. (2018), İlçe Belediye Çalışanlarının Örgütsel Bağlılık Düzeyleri: Aksaray İli Örneği, International Journal Entrepreneurship and Management Inquiries Dergisi, 2(2), s.64-73.

Mantere, S. \& Martinsuo, M. (2001), Adopting and Questionning Strategy: Exploring The Role of Cynicism and Dissent, 17th EGOS-Europen Group for Organisation Studies Colloquium, Lyon, France.

Mathews, B. \& Shepherd, J. (2002), Dimensionality of Cook and Wall's (1980) British Organizational Commitment Scale Revisited, Journal of Occupational and Organizational Psychology, 75(3), s.369-375.

Mclnnis, Kate J., John P. Meyer ve Susan Feldman (2009), Psychological Contracts And Their Implications For Commitment: A Feature-Based Approach, Journal Of Vocational Behavior, 74 (2), s.165-180.

Meyer, J. P., Stanley, L.J. \& Parfyonova, N.M. (2012), Employee Commitment In Context: The Nature And Implication Of Commitment Profiles, Journal Of Vocational Behavior, 80(1), s.1-16.

Meyer, J. P., Irving, G.P. \& Allen, N.J. (1998), Examination Of Combined Effects Of Work Values And Early Work Experiences On Organizational Commitment, Journal Of Organizational Behavior, 19(1), s.29-52.

Meyer, J. P., Stanley, D.J., Jackson, T.A., McInnis, K.J., Maltin, E.R. \& Sheppard, L. (2012), Affective, Normative, And Continuance Commitment Levels Across Cultures: A Meta-Analysis, Journal Of Vocational Behavior, 80 (2), s.225-245.

Meyer, J. P. \& Allen, N.J. (1991), A Three-Component Conceptualization Of Organizational Commitment, Human Resources Management Review, 1(1), s.61-89.

Mowday, R. T., Steers, R. M. \& Porter, L.W (1979), The Measurement Of Organizational Commitment, Journal Of Vocational Behavior, 14(2), s.224-247.

Nafei, W. A. (2013), The Effects Of Organizational Cynicism On Job Attitudes An Empirical Study On Teaching Hospitals In Egypt, International Business Research, 6(7), s.52-69.

Nafei, W. A. \& Kaifi, B.A. (2013), The Impact Of Organizational Cynicism On Organizational Commitment: An Applied Study On Teaching Hospitals In Egypt, European Journal Of Business And Management, 5(12), s.131-147.

Naus, F., Iterson, A.V. \& Roe, R. (2007), Organizational Cynicism: Extending The Exit, Voice, Loyalty, And Neglect Model Of Employees, Responses To Adverse Conditions In The Workplace, Human Relations, 60(5), s.683-718.

Obeng, K. \& Ugboro, I. (2003), Organizational Commitment Among Public Transit Employees: An Assessment Study, Journal Of The Transportation Research Forum, 57(2), s.83-98.

Oliver, N. (1990), Rewards, Investments, Alternatives And Organizational Commitment: Empirical Evidence And Theoretical Development, Journal Of Occupational Psychology, 63(1), s.19-31.

Özler, D., Atalay, C. \& Şahin, M. (2010), Örgütlerde Sinizm Güvensizlikle Mi Bulaşır? Organizasyon ve Yönetim Bilimleri Dergisi, 2(2), s.47-57.

Porter, Lyman W., Steers, R.M., Mowday, R.T. \& Boulian, P.V. (1974), Organizational Commitment, Job Satisfaction, And Turnover Among Psychiatric Technicians, Journal Of Applied Psychology, 59(5), s.603609.

Randall, Donna M. (1987), Commitment And The Organizations: The Organization Man Revisited, Academy Of Management Review, 12(3), s.460-471.

Reichers, A., Wanous, J. \& Austin, J. (1997), “Understanding And Managing Cynicism About Organizational Change", Academy Of Management Executive, 11(1), s.48-59.

Şenturan, Ş. (2014), Örnek Olaylarla Örgütsel Davranış, 1. Baskı, Beta Basım Yayım, Bursa.

Taş, Ö. (2012), Örgütsel Bağlılık, Örgütsel Güven ve İş Doyumu Arasındaki İlişki: Özel Bir Hastane Örneği, Unpublished Master's Thesis, Ankara University Health Sciences Institute, Ankara.

Torun, Y. (2016), Personel Güçlendirme ve İşten Ayrılma Niyeti İlişkisinde Örgütsel Sinizmin Aracılık Rolü: Örgütsel Sinizm Ölçeğini Geliştirmeye Yönelik Bir Araştırma, Unpublished PhD Dissertation, Marmara University, İstanbul.

Türköz, T., Polat, M. \& Coşar, S. (2013), Çalışanların Örgütsel Güven Ve Sinizm Algılarının Örgütsel Bağlılıkları Üzerindeki Rolü. Yönetim ve Ekonomi, 20 (2), s.285-302.

Uçar, P. \& Kök, S. B. (2018), Özel Banka Çalışanlarının Örgütsel Bağlılık Düzeyleri, Asia Minor StudiesInternational Journal of Social Sciences, 6, s.235-245.

Wasti, S. A. (2002), Affective And Continuance Commitment To The Organization: Test Of An Integrated Model In The Turkish Context, International Journal Of Intercultural Relations, 26(5), s.525-550.

Yavuz, Ayşe \& Bedük, A. (2016), Örgütsel Sinizm Ve Örgütsel Bağlılık Arasındaki İlişki: Bir Kamu Bankasının Konya Şubelerinde Örnek Bir Uygulama, Selçuk Üniversitesi Sosyal Bilimler Enstitüsü Dergisi, 35, s.301313.

Yıldız, K. (2013), Örgütsel Bağl1lık İle Örgütsel Sinizm Ve Örgütsel Muhalesef Arasındaki İlişki, International Periodical For The Languages, Literature And History Of Turkish Or Turkic, 8(6), s.853-879. 